
literary-criticism

\title{
ЖУРНАЛИСТИКА
}

\author{
МЕДИАТИЗАЦИЯ В ЦИФРОВУЮ ЭПОХУ: \\ ОТ ТРАНЗИТА К ТРАНСГРЕССИИ
}

\author{
JOURNALISM \\ MEDIATIZATION IN THE DIGITAL ERA: \\ FROM TRANSITION TO TRANSGRESSION
}

DOI: $10.22363 / 2312-9220-2021-26-4-597-622$

УДК 070:316.77

Editorial article / Редакционная статья

\section{Mediatization in New Normal: Reversive Paradigms and Provoking Transgression?}

\author{
Marina G. Shilina \\ Plekhanov Russian University of Economics, \\ 36 Stremyanny Ln, Moscow, 115093, Russian Federation \\ Lomonosov Moscow State University, \\ 9 Mokhovaya St, Moscow, 125009, Russian Federation \\ $\bowtie$ marina.shilina@gmail.com
}

Conflicts of interest. The author declares that there is no conflict of interest.

Acknowledgements. Our sincere thanks to the contributors and the many others who made this special issue possible, including the following: Professor Irina Volkova, Professor Valentin Stepanov and Professor Galina Sorina, Dr. Dmitrij Sharonov and Dr. Alexander Segal.

Article history: submitted: May 29, 2021; accepted: June 11, 2021.

For citation: Shilina, M.G. (2021). Mediatization in New Normal: Reversive paradigms and provoking transgression? RUDN Journal of Studies in Literature and Journalism, 26(4), 597-622. doi: 10.22363/2312-9220-2021-26-4-597-622 


\title{
Медиатизация в «новой нормальности»: реверсы парадигмы и провокации трансгрессии?
}

\author{
М.Г. Шилина \\ Российский экономический университет имени Г.В. Плеханова, \\ Российская Федераџия, 115093, Москва, Стремянный переулок, 36 \\ Московский государственный университет имени М.В. Ломоносова, \\ Российская Федерачия, 125009, Москва, ул. Моховая, 9 \\ $凶$ marina.shilina@gmail.com
}

Заявление о конфликте интересов. Автор заявляет об отсутствии конфликта интересов.

Благодарности. Выражаем искреннюю благодарность авторам и коллегам, которые сделали возможным издание этого специального выпуска. Особая благодарность Ирине Волковой, Валентину Степанову, Галине Сориной, Дмитрию Шаронову и Александру Сегалу.

История статьи: поступила в редакцию - 29 мая 2021 г.; принята к публикации - 11 июня 2021 г.

Для цитирования: Шилина М.Г. Медиатизация в «новой нормальности»: реверсы парадигмы и провокации трансгрессии? // Вестник Российского университета дружбы народов. Серия: Литературоведение. Журналистика. 2021. Т. 26. № 4. С. 597-622. doi: $10.22363 / 2312-9220-2021-26-4-597-622$

\section{New Normal dilemma: "Mediatize or die"?}

Nowadays, the global Coronavirus (COVID-19) pandemic provokes unprecedented change and sweeps through politics, economics, societies, cultures [1] — and mass media as well [2]. Meanwhile, the media is not only collapsed like other industries and social institutes. Paradoxically, it sweeps its own traditional professional, industrial and social boundaries to retain its brand perception as an indispensable and normative condition of our existence in this New Normal [3].

In the era of such mobilizing slogans as New Normal, Build Back Better and others, the mass media communication model and mediatization effects are changing dramatically, mostly due to digital platforms and their owners as its specific normative actors of the data colonialism [4]. Digital mediatization effects stay on the life's edge and a New Normal dictum sounds as - literally "mediatize or die" dilemma when in lockdown someone has no access to the Internet to check the hot news or pay for their food or medicine or to take their permission to leave lockdown zone, etc. 
New Normal is seemingly here to stay and in the near future according to the Pew Research Center and Elon University's Imagining the Internet Center research (2021), people's relationship with technology and tech determinism will deepen. The experts foresee significant change that will worsen economic inequality, enhance the power of big technology firms, multiply the spread of misinformation "as authoritarians and polarized populations wage warring information campaigns with their foes", etc. Some of the experts' express hope that changes spawned by the pandemic will make things better for significant portions of the population [5]. However, the imperativeness of mediation will grow, and traditional media communication modes, models and actors - and media effects - will change.

What does this New Normal change mean for media and mediatization studies? In other words, what is the impact on media and mediatization studies in the context of New Normal resulting from the pandemic, and how could it be theorized?

\section{Media, mediation and mediatization in New Normal: Quo Vadis and Qui Prodest?}

The evolution of modern media and media studies growth is connected with the evolution of capitalism and modernity. Since $17^{\text {th }}$ century, media became an instrument of new bourgeois stratum and remains an inseparable part of society and politics, economics and culture. In $20^{\text {th }}$ century, it cannot be divorced from contexts of everyday life [6]. In the 1950-60s Harold Innis, Marshall McLuhan, Raymond Williams and others defined media as one of the core mediators of society and its transformations. In the 1990s, Thompson analyses media effects in the context of modernity, and as one of the first determines media as institutional structures forming modern society and suggests mediatization as its function [7].

In the 2000s, the mass media is defined as being socially organized technologies for communication; mediated communication as a kind of intercourse that "makes use of such institutionalized tools that are primarily intended for communication"; mediatization as "an historical process whereby communication media become in some respect more "important" in expanding areas of life and society" and "expand in extension and power" [8. P. 484], especially in times of mediation of "everything' [9].

During the last decade, media studies and mediatization studies as its new specific direction have evolved due to (digital) diversity of media and its effects. Starting from the differentiation of mediation and mediatization, and discussing the essence of the studies, academic researchers are still trying to mark the borders of this research field [10].

The majority of researchers consider the mediatization phenomena to be best understood as a non-linear process through which the media influences culture 
and society. According to Stig Hjarvard, mediatization is a double-sided social process through which society is totally saturated with the media and it can no longer be viewed separately from other social institutions [11].

Mediatization is not only the process by which society is increasingly represented by the media, it becomes dependent on media and their logic. Media provokes limitation and distortion, such as through the use of exaggeration [12]. Friedrich Krotz presumes it is a meta process (i.e., similar to globalization) based on various forms of communication practice of social and cultural world construction [13]. At the same time, the boundaries of the media and social networks, professional journalism and "citizen journalism" are blurring.

The mediatization fundamentals were taken from the media and cultural studies and social science $[6,11]$. The researchers conceptualize media as a social institution, from a cultural and material "perspective" [14]. For instance, one of the last theoretical approaches of mediatization proposed by Nick Couldry and Andreas Hepp in "The Mediated Construction of Reality" (2016), was realized within the framework of the figurative approach of Norbert Elias (1978) [15] taken from social science, at the intersection of social and media studies, the socialconstructivist and cultural framework [16]. In 2020, the concept of digital 'deep mediatization' provided first by Couldry and Hepp advances the traditional sociological figuration and institutional approach [17]. Typology of mediatization studies includes such directions as institutionalist, social-constructivist, and material. Mediatization is classified as direct and indirect, at macro- and micro levels, etc.

To evaluate different effects, mediatization "demands cross-disciplinary work - with political science or pedagogy or the sociology of the family, for example - in ways too rarely attempted" [10]. For instance, socioeconomic context and effects are not included to the research agenda as a rule.

In the time before a New-Normal-past, even several years ago leading European researchers traditionally stressed, that "questions concerning the positive or negative outcomes of mediatization cannot, however, be answered on a general level; they must be addressed through an analysis of the specific contexts in which mediatization occurs and by explicating the normative framework of such evaluations" [14. P. 6].

The mediatization proponents mention that its concept is not just a concept reflecting the ever-increasing influence of media on different sectors of society and culture but a "paradigmatic shift" in media studies [6. P. 315] and social science in general.

The mediatization opponents argue that it is best understood as a sensitizing concept that guides empirical research and the interpretation of findings rather than as either a new paradigm or a middle-range theory in competition with others. They call on proponents of mediatization to understand social and media change within modernity within a variety of domains, in the context of existing theories and the other meta processes of modernity over a wide timescale (recent decades, centuries, millennia) [10]. 
How to analyze and theorize mediatization in the New-Normal-present? At the ICA 2020 conference, Andreas Hepp and Wiebke Loosen argued that it could be theorized as a 'mediatized collective break' during which all of us are experiencing the 'refiguration of public connection' [18]. In 2021, Hepp describes New Normal as deeply mediatized and identifies four points for analysis, such as people's expectations having been mediated, a mediated experience of the pandemic itself, an ongoing media-mediated analysis of the course the pandemic takes and repeatedly confrontation with the idea of a media-based 'solution' to individual problems brought up by the pandemic. "There are also "collective actors' who play an important role in the 'making' of deep mediatization", such as social movements, for example, the open-source movement, pioneer communities, etc." - he added [19].

This specific environment and situation creates a number of key questions and dilemmas in the field of media and communication studies. Does New Normal mean just the 'refiguration of public connection' to be analyzed and theorized by mediatization scholars? Does the traditional approach of analysis address the contexts in which mediatization occurs work in New Normal?

To describe change, there needs to be included in the research framework we are identifying some of the basic elements and aspects that drive the transformation parameters of mediatized communication models rooted in digitalization, datafication and Internetization. In the mid-2010s, the AI-driven datafied and mediated economy was rising as normative in the majority of developed and many developing countries. Media becomes (or has to become) a normative element of the so called quadro helix (4H) of innovative economics communication model ('state-to-business-to-science-to-citizens') [20]. It means that exactly media effects in $4 \mathrm{H}$ are strongly needed to evaluate effective communication. Thus, in a new type of datafied digital economy media effects and the mediatization framework of research - could be the most effective. It determines the expansion of the framework of mediatization, taking into account the realities of the quadro helix, social economy, economy of innovation, innovation communication, etc.

In the era of the Internet and the data colonialism, digital datafied mediated communication model a priory includes digital platform and data owner as the main normative autonomous media actors and (quasi) subjects. At all the levels of mediatization, macro (state), meso (institution), micro (individual). All of the subjects are influenced by data-driven mediation, provoked directly and indirectly by these (quasi) subjects and their specific media logic. However, these new core (quasi) subjects of datafied mediated economics are rather new for media studies [21] but determine the new structure and typology of mediatization studies.

Professional and social essence and function of the media differs due to media platforms. For instance, a media platform is not a 'traditional' institutional actor like media holding or supra-individual actor like state. As a normative (quasi) actor platform influences and transforms not only media and socio economy but politics and other spheres. The platform's media logic is radically different from all 
previously existing and studied media realities. Just two examples: in 2021, Twitter bans President Trump and Google decides to ban all of the opponents of the idea of global warming - and for the first time a media platform (and its owners) became not only an economic and social but a real independent political actor. Thus, even before the advent of the New Normal, media and mediatization are already significantly transformed. Let's explore some of the changes that can be defined, without exaggeration as being paradigmatic.

Firstly, the effects of mediatization are becoming more popular and more important than media effects. It means that in media studies, mediatization is becoming a leading trend. It allows us to confirm the relevance of the idea of mediatization as a 'paradigm shift' in media research (which is constantly being criticized). We propose to designate the current situation as a reverse paradigm shift.

Second, the effects of mediatization can no longer be limited to cultural and social effects; the disciplinary framework of research is significantly expanding even within the quadro helix of the digital economy. It necessitates a broader interdisciplinary approach (and also indicates the evolution and increasing importance of the concept of mediatization).

Thirdly, the effects of the functioning of media platforms, despite the specifics of their medialogic, have a significant impact not only on the mediatization, but all spheres of life. The media (platform) is transforming from $a$ tool of the traditional class and economic struggle of the bourgeoisie into a means of production for digital 'data colonizers'. In other words, the essence of media in the economy and society is changing radically and reversibly.

Nowadays, mediatization becomes a meta process that has been under the critique of academic research earlier [10]. It could not be possible to analyze mediatization phenomena by continuing to follow traditional mediatization studies borders, especially while they are blurring. As an open meta element and process of New Normal it needs a new conceptual meta vision.

\section{New Normal mediatization as transgression?}

Media is a tool of transition and change 'by origin'. According to Roger Silverstone, mediation requires us to understand how processes of communication change the social and cultural environments and vice versa [22]. The very next 'new' media provokes radical social and cultural transition and transgression (it is a commonplace that according to Plato, even Socrates expressed concern over writing as 'a new media tool'). Every emergent media is always surrounded by controversy because it presents a shift in patterns of communication and social structure that is potentially threatening to established powers [23].

Digitalization, internetization and datafication create the ground for radical socioeconomic and sociopolitical 'data turn' [20] and mediatization as a double reverse paradigm shift. In other words, it means a transgression (COVID-19 
pandemic and New Normal is a sort of transgression). De facto, transgression (trans means "through"; and gradi "to go", in Latin) is a fundamental characterristic of human existence and relation to reality, since the very transgressive separation of man from nature.

There is a history of transgression in society since $14^{\text {th }}$ century, and transgression research since last century seems to be challengingly transgressive and challenging transgression. The term and concept of transgression refers to (post)modernity and non-classic philosophy. The researchers insist that the German term 'Aufhebung' (the untranslatable German verb aufheben means to overcome while maintaining) which is close to transgression was proposed by Hegel in the "Phenomenology of Spirit". 'Aufhebung' means going beyond social being and achieving the position of an external observer in relation to the phenomena under consideration which describes only one of the possible meanings.

The essence of transgression as a phenomenon and process has many interpretations in various fields of science. Transgression is a space of transition from one fixed state to another. The term is fixing the phenomenon of crossing an impassable border, first of all, the border between the possible and impossible. Transgression as a violation of the border is possible only when and where such a border exists, and, on the other hand, the existence of the border presupposes its violation. Moreover, in certain cases, the border can be established as a result of a transgression, therefore it can be understood as a positive expansion of the boundaries. Transgression can be determined only by knowing the boundaries and only by an outside observer of the system.

Blurring norms, taboo and boundaries transgression permanently asserts and denies the limit at the same time and needs new transgression. Transgression describes the specific destructive and explosive, and innovative function or a social, cultural, political act or a characteristic. Paradoxically, to transgress is to go beyond the bounds or limits set by a commandment or law or convention, it is to violate or to infringe. And to transgress is also more than this, it is to announce and even to contradict a commandment, the law or convention. Transgression is a deeply reflexive "act of denial and affirmation" [24. P. 2].

According to Blanchot, transgression "is overcoming an insurmountable limit" [25]. For Bataille, the "transgressive way of thinking' is a sort of 'inner experience' and a sort of hedonistic autism [26]. He substantiates the philosophical, literary, economic, theological strategies of transgression and convinces that it lifts the prohibition without destroying it. Sometimes, the exception is more interesting than the normal case because it "not only confirms the rule, the rule itself exists only due to the exception" [27].

Gournels and Gunkel consider that "first, transgression is a social fact that is not completely contained within, and not completely apart from the social; second, transgression is anomalous but necessary to the functioning of the norm, what Slavoy Žižek ... has termed 'a constitutive exception'; third, transgression works beyond mere opposition and resistance to an inhabited Other; fourth, transgression embraces desire and play in order to self-consciously question the 
stasis and seriousness of the status quo, and thus while its politics are ambivalent, its power is both unquestionable and necessary" [28. P. 8].

Transgression is realized on two levels: at an institutional and individual level of transgression, which do not exclude each other. However, at meta level transgression is a specific original version of anthropological and sociogenesis. It is obvious as a striving beyond the boundaries of rationality and expediency of capitalism, especially in the data colonialism era. (Is it possible that the New Normal is the next stage? Then the transgression becomes the key approach to any research.)

Transgression is one of early cultural studies' key terms used in media cultural studies. Discourse on transgression dominates social and cultural studies and media culture in particular. For instance, one of the most widespread ideas, models and analytic categories is carnival as a phenomenon of socially permitted transgression, described by Bakhtin in "Rabelais and his Word' (1965) [29], and widely used not only in cultural and media cultural but also in political studies and related disciplines.

Nowadays, media researchers traditionally are interested in a variety of transgression 'taboo-breaking' topics but it's rather narrowly focused, not the cross-disciplinary or complex analysis of mediatization in dozens of articles. For instance, the authors of the special Transgression series of Amsterdam University publishing house explore such topics as analysis of forms of media culture that violate moral, legal, cultural and social limits; high theory and its use in the context of transgressive media culture discourse; Trans, in any variety e.g. human-species-gender-sexuality, and so forth [30]. Researchers of transgression in digital era and digital 2.0 are also deeply connected only with topics of media culture, such as mediatized political mashups, sex, pornography and other "nonconventional" scientific problems [28].

In 2021, the latest special issue of the International Journal of Cultural Studies on media and transgression inquiries into the uses of transgression as a critical concept to query contemporary media culture which is discussed in case studies from political satire to online trolls. According to the editors, nowadays "transgression points to the energy that fuels the media ecology - from content and content production to audience practices and the policing of content ownership". The researchers are focused on such problems as the (conscious) overstepping of moral and legal boundaries, that challenges written and unwritten rules. They claim that "frisson of rule breaking and the reward of rule reestablishment (whether by powerful parties or everyday gossip) are transgression's bookends. Together they support the cyclical rhythm of media culture that maintains not just our interest as viewers but our interests and connectedness as citizens, whether in celebration, outrage or condemnation" [31].

Therefore, staying at the 'not-to-distant-past' theoretical, conceptual, methodological and thematic position, mediatization theorists do not reflect the transgression effects of growing media 'meta invasion' in New Normal. However, in New Normal the provocative concept of transgression provides some new 
lenses through which we could see and understand mediatization as a meta process transgressing not only culture and society but economics and politics, more comprehensively and study it cross-disciplinary. Universal total of New Normal transgression engages with interdisciplinary areas and methodologies, including those drawn not only from media and mediatization studies, social science and philosophy, but beyond from economy and politics, etc. and opens up a pioneering approach for media research.

\section{Mediatizations and transgression: Mapping the research field}

In mediatization studies, the concept of transgression allows us to reveal the transgressive and analyze the ways of its expression in New Normal almost for the first time. The Russian RUDN Journal of Studies in Literature and Journalism presents a pioneering attempt to explore mediatization through its empirical and theoretical analysis using the lens of transgression. In this special issue of the RUDN journal we wish to explore the many ways in which media are embedded in current total transgression and to start mapping the research field despite the fact that transgression means the destruction of any boundaries.

The aim is both to substantiate the theory of mediatization and provide a richer understanding of the role of the media in current both global and local mediatized changes. Of course, there are more questions than answers in this field of mediatization research and in this special issue. But we hope it helps the reader himself to put together from the scattered, at the first glance, topics the contour of the general map of transgression mediatization in New Normal.

The first section of the Journal is theoretical. Our study identifies the "reverse" paradigm shift and characteristics that reinforce the special place of mediatization studies in medialogy. In the New Normal at the meta level, the idea of transgressive mediatization as a complex vision of actual practices and their conceptualization is proposed. The new concept 'opens the boundaries' of the classical field of research for interdisciplinary analysis.

The institutional essence of media transgression is the first paper! In his research, Viktor Kolomiets implements the idea of mediatization as a process of transformation of media as it is. He analyzes the mass communication industry under the pressure of digital transit, which breaks traditional business practices and is transgressive by definition. Behind the industrial transformation the more crucial conflict is seen between the relatively free digital environment and the institutionalized state-controlled media.

Journalism is a traditional 'core sphere' of media but its existence nowadays seems to be very contradictory due to a great number of challenges perceived by the media themselves. Greg Simons and Dmitry Strovsky are breaking the rules to find out that the interactions and reactions between the cognitive imaginations of the ideal form of journalism and the physical realities of the forces shape and 
affect the profession - and find another sense of transgression in journalism. The institutional boundaries and practices of the profession are under a great deal of strain between the ideal imaginations and expectations. There is cumulative effect of the ideas and elements, proposed by the authors could be a revolution from the original academic vision and conception of practice.

In recent decades social media is also rather a traditional mediatization field. To describe the ontology of transgressive social media, Valentin Stepanov proposes the T-Magic formula. Three Ts stands for transformation, transfiguration and transgression. It displays digital space and digital time navigation. Pioneering ideas of research allow Stepanov to discuss social media and social capital, anthropology of digitalization from this point of view.

The theoretical foundations of transdiscursiveness, proposed by Anna Kostikova and Sergei Spartak, allow us to fix its new characteristics in the conditions of crucial digitalization of society. In response to the crisis of understanding in mediatized everyday life, the authors turn us back to the idea of discursivity of human civilization and propose to rethink the concept of possible worlds - to renew social strategies and communications in terms of the philosophy of language.

The problem of strengthening biopolitical control as a consequence of the corporeality deep mediatization is discussed by Ekaterina Alekseeva. The article argues that the deep mediatization of corporeality is a complex and inevitable process. The author suggests that theoretical approaches such as cyberfeminism or xenofeminism show that the corporeality deep mediatization as a transgressive alliance of people, media and technology can open up new opportunities for creating different life forms out of control.

Marina Shilina and Julie Wirth analyze the communication essence of an immersive media project. To designate the research direction into the essence and effects of immersive media practices, the authors propose the term 'generative mediatization' to describe the effects of personal and socio-cultural development obtained by the user and based on experience. Such a new type of transgressive user experience deepens the user-centric approach and provokes a new paradigm shift in mediatization studies.

To find new theoretical ideas, Evgenia Nim provides the analysis of the possibilities and limitations of the figurative approach to the deep mediatization study. The researcher proposes to analyze the multifunctional platforms that become a single digital infrastructure for many figurations and could be the ecosystem for a mediatized social life and use a more radical interpretation of media logics as human-machine logics.

The second section of the journal opens up the transgressive optics for empirical studies of mediatization. The article by Sergei Samoilenko supports Valentini's (2006) observation that the EU's inability to tailor its message to different audiences. In the context of European mediatized politics, the idea of an integrative European identity is unlikely to become a unifying power for the fragmented citizenry. Audience segmentation and fragmented media lead to 
multiple transgressions including the formation of new public spheres and growing ideological polarization.

In Kazakhstan, omni-mediatization became the strategy for political parties and opposition movements, according to Mariyamgul Kussainova. She analyses the transgressive concept of transmedia storytelling as a promising direction of their strategies. Author is of the opinion that the main features of mediatization of public policy in Kazakhstan are a paternalistic format of interaction and politics through social media to protect society from surrogate opposition, "the growth of political populism" and disinformation.

Theorizing mediatization, Can Bilgili and Olena Goroshko focus on discussions and research on the intertwining of the media with the awareness of the audience (or consumer) about the content of transmedia stories in the context of media literacy. The study focuses on the Turkish and Ukrainian audience knowledge about transmedia applications. They examine the competence of multimedia viewers who use social media and follow traditional media - the television channel - to understand and be aware of the content transitions between different media tools and platforms. Television was chosen as the traditional media for the research study due to its widespread viewing in Turkey and Ukraine.

Dmytrij Sharonov analyzes the concept of hypermedia as a transgressive aspect of deep mediatization of the relationship between the company and its stakeholders. He concretizes the model of recursive communication for the correct interpretation of the discovered phenomena. The author believes that the philosophical reflection, ecological approach and transition to trans-disciplinary methods of researching the problems of deep mediatization in the digital era is inevitable.

Larisa Sharakhina, Vera Achkasova and Liudmila Azarova point out that the media and the environment crucially shape each other and operating conditions for other institutions. For the first time, the authors use mediatization optics for corporate communication and media relations strategies analysis and find the specific discursive "configurations of configurations" built up in layers, constantly referencing each other.

In times of social media, social institutions are affected by media, particular in medicine. Marina Shutova and Yana Rocheva focus on the new interaction clinic-to-doctor-to-patient digital mediated models. Pioneering study of the transformative effect of mediatization in medicine reveals the efficiency of communicative constructivism, validates the transformation tendencies in medicine as a social institution and blurs the boundaries of the traditional research field.

Growing ubiquitous digitalization of mediatized communication, especially in New Normal, provokes the interest of Elena Chankova and Oleg Sorokin to the phenomenon of communicative competence of an individual. The researchers insist that the communicative competence of an individual is a factor which determines the effectiveness of interactions in the context of technological, semantic and institutional changes and the integration of the communicative space of society. 
In the third section of the Journal the reader can compare realities of mediatization in a global and local theoretical context while reading the interviews with the leading researchers in their fields, Professor Andreas Hepp and Professor William Dutton.

Many of these pioneering research questions left wide open. Nevertheless, mapping transgressive New Normal mediatization research field the contributors of this special issue stay pioneers, literally and metaphorically. Let us, together with the authors of this special issue of Mediatization in the Digital Era: From Transition to Transgression, cross all the boundaries because only an external observer of any system has the most interesting and rewarding view and role, which is paramount especially for a scientist. Bon voyage and good luck!

\section{RUS}

\section{Дилемма «новой нормальности»: медиатизация или смерть?}

Глобальная пандемия SaRS-COVID-19 вызывает беспрецедентные изменения во всех сферах — экономике, обществе, культуре [1], — и в медиа [2]. Однако СМИ, как ни парадоксально, не только оказались в «зоне поражения», как другие отрасли и социальные институты, но и расширили собственные традиционные профессиональные, производственные и социальные границы, поскольку оказались непременным и, по существу, нормативным условием нашего существования в нынешней «новой нормальности» [3].

В «новой нормальности» модели медиакоммуникации и эффекты медиатизации кардинально меняются, в основном благодаря цифровым платформам и их владельцам как нормативным акторам эпохи Big data колониализма - колониализма «больших данных» [4]. Современные эффекты цифровой медиатизации балансируют на грани жизни: слоган «новой нормальности» звучит буквально как дилемма: «Медиатизация или смерть!», — когда в условиях изоляции у человека нет доступа к Интернету, чтобы проверить горячие «ковидные» новости, заплатить онлайн за еду или лекарства или взять пропуск, чтобы выйти из дома...

«Новая нормальность» останется с нами и в ближайшем будущем, согласно данным исследовательского центра Pew Research Center и Университета Илона (Imagining the Internet Center, 2021), люди и технологии будут связаны еще теснее. Эксперты предвидят значительные изменения, которые усугубят экономическое неравенство, усилят влияние крупных технологических корпораций, умножат объемы дезинформации, авторитарные и поляризованные группы населения, будут вести «враждебные информационные кампании со своими противниками» и т. д. Некоторые эксперты при этом выражают надежду, что постпандемийные изменения улучшат положение 
людей [5]. Как бы там ни было, сфера императивной медиатизации будет продолжать расширяться, традиционные медийные способы коммуникации, модели, акторы, медиаэффекты - изменяться.

Какие вызовы возникают в «новой нормальности» с точки зрения исследований медиа и медиатизации? Иными словами, каковы особенности медиа, медиатизации и их исследований в контексте «новой нормальности»?

\section{СМИ, медиация и медиатизация в «новой нормальности»: Quo Vadis и Qui Prodest?}

Эволюция современных медиа и развитие медиаисследований тесно связаны с эволюцией капитализма и общества модерна. СМИ как инструмент влияния нарождающегося нового класса буржуазии в XVII веке вскоре становятся неотъемлемой частью общества и политики, экономики и культуры. В XX веке медиа невозможно исключить из контекстов повседневной жизни [6]. В 1950-1960-е годы Г. Иннис, М. Маклюэн, Р. Уильямс и другие исследователи определили СМИ как один из основных медиаторов общественных процессов и преобразований. В 1990-х годах Дж.Б. Томпсон анализирует медиаэффекты в контексте современности и - среди первых определяет медиа как институциональные структуры, формирующие современное общество, и описывает медиатизацию как функцию СМИ [7].

В 2000-е годы ученые определяют медиа как социальные организованные коммуникационные технологии; опосредованное медиаобщение - как вид коммуникации, в котором «используются такие институционализированные инструменты, которые в первую очередь предназначены для общения»; медиатизация описывается как «исторический процесс, посредством которого средства коммуникации становятся в некотором отношении более „важными“ в расширении сфер жизни и общества» и благодаря этому «ширятся и обретают силу» [8. Р. 484], особенно в нынешние времена «медиатизации всего» [9].

В последнее десятилетие изучение медиа - и исследования медиатизации как нового специфического направления медиалогии - эволюционирует в контексте роста (цифрового) разнообразия медиа и их эффектов. При этом ученые, начав с разграничения медиации и медиатизации и дискуссий о сущности медиатизации как сферы научных изысканий, пока лишь обозначают параметры и возможные границы этого исследовательского поля [10].

Большинство исследователей рассматривают феномен медиатизации как нелинейный процесс, посредством которого медиа влияют на культуру и общество. По мнению С. Ярварда, медиатизация - это двусторонний социальный процесс, благодаря которому общество полностью (предельно Прим. авт.) насыщается средствами массовой информации, которые больше нельзя рассматривать отдельно от других социальных институтов [11]. 
Медиатизация - это не только процесс, благодаря которому общество все больше опосредовано медиа, - социум становится зависимым от СМИ и их логики. Медиа провоцируют искажения, например преувеличение [12]. Ф. Кротц полагает, что медиатизация - это метапроцесс (подобный, к примеру, глобализации), основанный на различных формах коммуникативной практики построения социального и культурного мира [13]. При этом границы СМИ и медиапотоков социальных сетей, профессиональной журналистики и «журналистики граждан» размываются.

Теоретические основы медиатизации ученые черпают из медиалогии, культурологии и социальных наук [6.P. 11], концептуализируя медиа как социальный институт, с позиций культурной и материальной «перспектив» [14]. В частности, один из актуальных теоретических подходов к изучению медиатизации предложен Ником Коулдри и Андреасом Хеппом в работе «Медиаконструирование реальности» (2016) в рамках фигуративного социологического подхода Норберта Элиаса (1978) [15], на стыке социологии и медиалогии, социально-конструктивистского и культурологического подходов [16]. В 2020 году концепция цифровой «глубокой медиатизации», впервые предложенная Н. Коулдри и А. Хеппом, развивается в рамках традиционного социологического фигуративного подхода [17].

Типология исследований медиатизации включает институциональное, социально-конструктивистское и «материальное» направления. Медиатизация рассматривается как прямая и косвенная, на макро- и микроуровне, социальном и индивидуальном и т. д. Оценка эффектов медиатизации «требует междисциплинарного исследования, например, совместного с политологией, педагогикой или социологией семьи, что происходит крайне редко» [10]. Так, например, социально-экономический контекст и эффекты, как правило, не включаются в повестку исследований.

В период до «новой нормальности», буквально несколько лет назад, ведущие европейские исследователи традиционно подчеркивали, что «на вопросы, касающиеся положительных или отрицательных результатов медиатизации, нельзя, однако, ответить на общем уровне; они должны решаться посредством анализа конкретных контекстов, в которых происходит медиатизация, и путем объяснения нормативных рамок таких оценок» [14. Р. 6].

При этом сторонники медиатизации отмечали, что это - не просто концепция, отражающая все возрастающее влияние медиа на различные слои общества и культуры, но и «парадигмальный сдвиг» в исследованиях медиа [6. Р. 315] и общественных наук в целом.

Противники же медиатизации утверждают, что ее оптимально воспринимать не как новую парадигму или теорию среднего уровня, конкурирующую с другими теориями аналогичного уровня в медиалогии, но как сенсибилизирующую концепцию, которая определяет направления эмпирических исследований и интерпретацию результатов. Ученые-критики предлагают сторонникам медиатизации изучать социальные и медийные изменения во 
всех сферах в контексте уже существующих теорий, в рамках других метапроцессов современности, в широком временном масштабе (например, последних десятилетий, столетий, тысячелетия) [10].

Каковы подходы к анализу и концептуализации медиатизации в «новой нормальности»? На конференции крупнейшей международной ассоциации исследований коммуникации International Communication Association (ICA) в 2020 году немецкие ученые Андреас Хепп и Вибке Лоозен утверждали, что в ковид медиатизацию можно теоретически обозначить как «коллективный перерыв» («mediatized collective break»), во время которого все мы переживаем «рефигурацию связей в обществе» («refiguration of public connection») [18]. В 2021 году Хепп описывает «новую нормальность» как глубоко медиатизированную и выделяет четыре направления для анализа медиатизированных реалий: ожидания людей, опыт самой пандемии, анализ хода пандемии и идеи «решения» отдельных ее проблем в СМИ. Ученый отмечает «коллективных акторов», которые играют важную роль в «глубокой медиатизации» и требуют изучения, например социальное движение за открытый исходный код, сообщества технологических пионеров и т. д. [19].

Является ли «новая нормальность» очередным форматом классической «рефигурации связей в обществе»? Возможно ли анализировать и концептуализировать медиатизацию в «новой нормальности» с помощью классических подходов?

Прежде чем определить характер практик и направления возможных подходов к исследованию медиатизации в «новой нормальности», обозначим некоторые из основных параметров трансформации медиатизации (на уровне моделей) в период «до-новой-нормальности», обусловленных цифровизацией, датафикацией и интернетизацией, которые, однако, не нашли отражения в исследованиях. Так, в середине 2010-х годов цифровая экономика, основанная на Big Data, больших данных, и технологиях искусственного интеллекта, становится нормативной в большинстве развитых и многих развивающихся странах. СМИ становятся (или должны стать) нормативным элементом, который обеспечивает функционирование так называемой квадроспирали инновационной экономики («государство - бизнес наука - граждане»), то есть медиа становятся обязательным «пятым элементом» цифровой экономики, формируя новую модель «квинтоспирали» [20]. Эффективное функционирование цифровой экономики означает, что именно медиаэффекты необходимо учитывать при обеспечении взаимодействия всех акторов в «квадроспирали». Таким образом, в цифровой экономике более всего востребованы именно медийные эффекты, их исследование обусловливает расширение рамок медиатизации с учетом реалий квадроспирали, социальной экономики, экономики инноваций, инновационной коммуникации и т.д.

В эпоху Интернета, так называемого Web 2.0 и особенно «датифицированного колониализма», модель цифровой медийной коммуникации априори 
включает цифровую платформу и владельца данных как базисных автономных (квази)субъектов. На всех уровнях медиатизации - макро (государство), мезо (социальный институт), микро (индивид) - коммуникация всех иных субъектов и объектов опосредована прямо или косвенно упомянутыми выше (квази)субъектами и подчинена их специфической медиалогике. Изучение этих базисных (квази)субъектов цифровой экономики довольно ново для исследователей [21], однако именно медиаплатформы определяют новую структуру и типологию медиатизации.

В условиях доминирования медиаплатформ изменяются не только параметры медиатизации, но и функции медиа, их профессиональная, индустриальная и социальная сущность. Платформы и их владельцы трансформируют не только медиа, общество и культуру, но и экономику, политику и другие сферы. Медиаплатформа при этом не является «традиционным» институциональным субъектом как медиахолдинг, или надындивидуальным субъектом - как государство. Медиалогика платформы радикально отличается от всех ранее существовавших и исследованных медийных реалий. Приведем всего два примера: в 2021 году Twitter «банит» тогдашнего президента США Трампа - и впервые медиаплатформа и ее владельцы выступают не только как экономический, социальный, но и как автономный политический актор; Google принимает официальное решение «банить» на своих ресурсах всех противников идеи глобального потепления, то есть фактически вводит глобальную цензуру и расправляется с неугодным для владельцев компании «научным инакомыслием».

Таким образом, уже до «новой нормальности», медиа и медиатизация существенно трансформируются. Зафиксируем два изменения, которые возможно определить - без преувеличения - как парадигмальные.

Во-первых, эффекты медиатизации становятся максимально востребованными и более важными, чем медиаэффекты. Это означает, что медиатизация становится ведущим направлением в медиалогии, что позволяет подтвердить релевантность идеи медиатизации как «сдвига парадигмы» в исследованиях медиа (хотя это направление постоянно подвергается критике). Сложившуюся ситуацию предлагаем обозначить как обратный, реверсивный сдвиг парадигмы.

Во-вторых, эффекты медиатизации уже невозможно ограничивать только культурными и социальными эффектами; дисциплинарные рамки исследования существенно расширяются - даже в границах квадроспирали цифровой экономики, что обусловливает необходимость более широкого междисцилинарного подхода (и также косвенно свидетельствует об эволюции и повышении значимости концепции медиатизации).

В-третьих, эффекты функционирования медиаплатформ, несмотря на специфику их медиалогики, оказывают существенное влияние не только на параметры медиатизации, но и трансформации во всех сферах жизни. Медиа (платформа) трансформируется из инструмента традиционной классовой и 
экономической борьбы буржуазии в средство производства для цифровых «колонизаторов» данных. Другими словами, сущность медиа в экономике и обществе меняется радикально - и реверсивно.

В «новой нормальности» медиатизация трансформируется еще более радикально, становится метапроцессом (что ранее подвергалось критике со стороны академических исследователей [10]).

Таким образом, невозможно анализировать феномен медиатизации, оставаясь в рамках традиционных частных, не кросс-дисциплинарных, не метасущностных границ исследований, тем более когда они взламываются. Медиатизация как открытый метаэлемент и метапроцесс «новой нормальности» нуждаются в новом концептуальном метавидении.

\section{Медиатизация в «новой нормальности» как трансгрессия?}

Медиа - это инструмент перехода и перемен «по определению». По мнению Р. Сильверстоуна, медиация предлагает нам понимание того, как процессы коммуникации изменяют социальную и культурную среду и vice versa [22].

Каждое «новое» медиа всегда вызывает споры, потому что провоцирует изменения в моделях коммуникации и социальной структуре, что потенциально угрожает установленному порядку вещей [23].

Каждое «новое» медиа провоцирует радикальный социальный и культурный переход — и трансгрессию (еще Сократ, если верить Платону, выражал озабоченность по поводу письменности как «нового медиаинструмента»).

Цифровизация, интернетизация и датафикация, как доказывают наши исследования, создают основу для радикального социально-экономического и социально-политического «поворота», Data Turn [20] и двойного «реверсивного» сдвига парадигмы в медиатизации. Другими словами - для трансгрессии. (Можно считать и саму пандемию COVID-SaRS-19, и «новую нормальность» своего рода трансгрессией.)

De facto трансгрессия (лат. trans - через; gradi - идти) является фундаментальной характеристикой человеческого существования и отношения к реальности, начиная с момента отделения человека от природы.

История трансгрессии в обществе с XIV века и ее исследования с века прошлого бросают вызов трансгрессии и кажутся вызывающе трансгрессивными.

Термин и концепция трансгрессии относятся к (пост)современности и неклассической философии. Исследователи настойчиво повторяют, что немецкий термин Aufhebung (непереводимый немецкий глагол aufheben означает «преодолевать, сохраняя»), близкий к трансгрессии, был предложен Гегелем в «Феноменологии духа». По сути, Aufhebung отражает только одно 
из возможных значений и означает выход за пределы социального бытия и достижение позиции внешнего наблюдателя по отношению к рассматриваемым явлениям.

Сущность трансгрессии как явления и процесса имеет множество трактовок в различных сферах научного знания. Трансгрессия - это переход из одного фиксированного состояния в другое. Термин фиксирует явление пересечения непроходимой границы - прежде всего границы между возможным и невозможным.

Трансгрессия - как нарушение границы - возможна только тогда и там, где такая граница существует, то есть может быть определена только благодаря знанию границ и только сторонним наблюдателем системы. С другой стороны, разве само наличие границы не предполагает ее нарушение? Более того, создание границы как таковое есть изменение, то есть нарушение, так что трансгрессию можно понимать и как процесс устранения нарушений.

Размывание норм, табу и нарушение границ постоянно утверждает и отрицает предел одновременно — и требует новой трансгрессии.

Трансгрессия - «глубоко рефлексивный акт отрицания и утверждения» [24. Р. 2], акт социальный, культурный, политический - или свойство. Это деструктивная и взрывоопасная — и новаторская — функция.

По мнению М. Бланшо, трансгрессия «преодолевает непреодолимый предел» [25]. Для Ж. Батая «трансгрессивный образ мышления» - это своего рода «внутренний опыт» и своего рода гедонистический аутизм [26]. Он обосновывает философские, литературные, экономические и теологические стратегии трансгрессии и убеждает, что они снимают запрет, но не разрушают его. Согласно К. Шмитту, иногда исключение более интересно, чем норма, потому что оно не только подтверждает правило, но и само правило существует только благодаря исключению [27].

Т. Гоурнелс и Д.Дж. Гункель считают, что «во-первых, трансгрессия это социальный факт, который социален и асоциален одновременно; вовторых, нарушение аномально, но необходимо для функционирования нормы, это то, что Славой Жижек назвал „конститутивным исключением“; в-третьих, проступок выходит за рамки простого противостояния и сопротивления Другому; в-четвертых, трансгрессия включает в себя желание и игру, чтобы осознанно подвергнуть сомнению застой и серьезность статус-кво, и, таким образом, хотя суть трансгрессии амбивалентна, ее сила неоспорима и необходима» [28. Р. 8].

Трансгрессия реализуется на двух уровнях: как институциональная, так и индивидуальная, не исключающие друг друга. На метауровне - это специфическая версия антропо- и социогенеза. В эпоху капитализма, особенно датифицированного колониализма, трансгрессия отражает стремление выйти за рамки рациональности и целесообразности. (Возможно ли, что «новая нормальность» - это следующая стадия? Тогда трансгрессивный подход может оказаться ключевым для всякого исследования.) 
Трансгрессия - один из базовых терминов времен ранних культурологических исследований. В медиакультуре дискурс о трансгрессии доминирует. Например, одной из наиболее распространенных идей, моделей, метафор и аналитических категорий является карнавал как феномен социально разрешенного нарушения, описанный М.М. Бахтиным в исследовании «Творчество Франсуа Рабле и народная культура средневековья и Ренессанса» (1965) [29] и широко используемый в сфере исследований не только культуры, медиакультуры, но и политики и др.

В настоящее время исследователи медиа традиционно интересуются широким спектром тем, нарушающих табу, что предполагает довольно узкую фокусировку, но не междисциплинарный или комплексный анализ медиатизации. Например, авторы специальной серии «Трансгрессия» издательства Амстердамского университета исследуют такие темы, как анализ форм медиакультуры, которые нарушают моральные, правовые, культурные и социальные ограничения и т.д. [30].

Исследования трансгрессии в цифровую эпоху и digital 2.0 также связаны исключительно с темами медиакультуры, такими как политизированные политические мэшапы, секс, порнография и другие «нетрадиционные» научные проблемы [28].

В 2021 году в специальном выпуске международного журнала исследований медиа и трансгрессии трансгрессия обозначена как критический фокус для изучения современной медиакультуры, от политической сатиры до онлайнового троллинга. По мнению редакторов этого специального выпуска Дж. Хермес и А. Хилл, в настоящее время «трансгрессия указывает на энергию, подпитывающую экологию СМИ - от контента и производства контента до практик аудитории и контроля за обладанием контентом». Исследования затрагивают такие проблемы, как (сознательное) превышение моральных и правовых границ, которое бросает вызов писаным и неписаным правилам. Хермес и Хилл утверждают, что «дрожь от нарушения правил и вознаграждение за восстановление правил (будь то влиятельные партии или повседневные сплетни) — это баллы проступков. Вместе они поддерживают циклический ритм медиакультуры, который поддерживает не только наши интересы как зрителей, но и наши интересы и связи как граждан, будь то празднование, возмущение или осуждение» [31].

Таким образом, придерживаясь в изучении концепции трансгрессии и ее применении теоретической, концептуальной, методологической и тематической классической позиции «прошлого-до-новой-нормальности», теоретики медиатизации не отражают пока трансгрессивные эффекты растущего «метавторжения» медиа в эпоху «новой нормальности».

Однако провокационная концепция трансгрессии дает возможность рефлексии медиатизации как метапроцесса, взрывающего не только культуру и общество, но и экономику и политику, - и фокусировку для более комплексного изучения медиатизации на междисциплинарном уровне. Уни- 
версальность концепции позволяет интегрировать в исследования медиатизации идеи не только социальных наук и культурологии, но и философии, экономики, политики и т. д. - и открывает новаторский подход к междисциплинарным комплексным исследованиям медиа в «новой нормальности».

\section{Медиатизация и трансгрессия: картография исследования}

Концепция трансгрессии позволяет впервые выявить и проанализировать специфику медиатизации в «новой нормальности».

Российский журнал исследований в области литературы и журналистики — «Вестник РУДН» - представляет читателю новаторскую попытку исследования медиатизации с использованием трансгрессивной оптики. В этом специальном выпуске журнала «Медиатизация в цифровую эру: от транзита к трансгрессии» мы хотим исследовать многообразие точек соприкосновения медиа и трансгрессии, начать составление карты исследования - несмотря на то, что трансгрессия предполагает разрушение любых границ.

Наша цель - предложить и обосновать новые идеи теории и практики медиатизации для более глубокого понимания сущности медиа, их роли в текущих глобальных и локальных изменениях.

Конечно, в медиатизации как сфере исследования - и в этом специальном выпуске - вопросов больше, чем ответов. Но мы надеемся, что этот специальный выпуск поможет читателю составить из разрозненных, на первый взгляд, тем контуры общей карты медиатизации и трансгрессии в «новой нормальности».

Раздел «Теория и методология: трансгрессия трансформации» - теоретический. Исследование характеристик медиатизации позволило выявить «обратную» смены парадигмы и характеристики, которые закрепляют особое место mediatization studies в медиалогии. В «новой нормальности» на метауровне предложена идея трансгрессивной медиатизации как комплексного видения актуальных практик и их концептуализации. Новая концепция «открывает границы» классического поля исследования для междисциплинарного анализа.

А пока - институциональная сущность трансгрессии прежде всего! Виктор Коломиец в своем исследовании реализует идею медиатизации как процесса трансформации медиа. Автор анализирует индустрию массовых коммуникаций в тисках цифрового транзита, который ломает традиционные методы ведения бизнеса и является трансгрессивным по определению. За индустриальной трансформацией виден и более существенный конфликт между относительно свободной цифровой средой и институционализированными СМИ, которые контролируются государством.

Журналистика - это традиционная «основа» медиа. Грег Саймонс и Дмитрий Стровский нарушают правила и разрушают стереотипы, выясняя, 
что институциональные границы и практики профессии противоречат идеальным представлениям и ожиданиям. Совокупный эффект идей, предложенных авторами, представляется революционным - в сравнении с академическим видением и концепциями.

В последние десятилетия социальные сети становятся традиционной сферой медиатизации. Валентин Степанов предлагает онтологию трансгрессивных социальных сетей — в виде формулы Т-Magic. Три буквы «Т» обозначают трансформацию, трансфигурацию и трансгрессию. Формула отображает цифровое пространство и цифровую навигацию во времени. Новаторское исследование включает анализ социальных сетей и социального капитала, антропологию цифровизации.

Теоретические основы трансдискурсивности, предложенные Анной Костиковой и Сергеем Спартаком, позволяют зафиксировать ее новые характеристики в условиях цифровизации общества. Авторы возвращают нас к идее дискурсивности человеческой цивилизации - в ответ на кризис понимания в медиатизированной повседневной жизни - и предлагают переосмыслить концепцию цифровых миров, обновить социальные стратегии и коммуникации с точки зрения философии языка.

Проблема усиления биополитического контроля как следствие телесности в условиях глубокой медиатизации рассматривается в статье Екатерины Алексеевой. Глубокая медиатизация телесности - сложный и неизбежный процесс. Автор полагает, что теоретические подходы, такие как киберфеминизм или ксенофеминизм, показывают, что глубинная медиатизация телесности как трансгрессивный альянс людей, медиа и технологий может открыть новые возможности для создания различных форм жизни, выходящих из-под контроля.

Марина Шилина и Юлия Вирт анализируют коммуникации иммерсивного медиапроекта. Чтобы обозначить новое направление исследования сущности и эффектов иммерсивных медиапрактик, авторы предлагают термин «генеративная медиатизация» для описания опыта и эффектов личного и социокультурного развития, которое получает пользователь. Этот новый тип трансгрессивного пользовательского опыта провоцирует новый сдвиг парадигмы в исследованиях медиатизации.

Чтобы найти новые теоретические идеи, Евгения Ним проводит анализ возможностей и ограничений фигуративного подхода к исследованию глубокой медиатизации. Исследователь предлагает проанализировать многофункциональные платформы, которые становятся единой цифровой инфраструктурой для многих конфигураций и могут быть экосистемой для медиатизированной социальной жизни, а также использовать более радикальную интерпретацию медиалогики - как логики человеко-машинной.

Следующий раздел журнала открывает возможности трансгрессивной оптики для эмпирических исследований медиатизации. Статья Сергея Самойленко отражает реалии неспособности ЕС адаптировать свое послание к разным аудиториям. Автор подчеркивает, что в контексте европейской ме- 
диатизированной политики идея интегративной европейской идентичности вряд ли станет объединяющей силой для граждан. Сегментация аудитории и фрагментарность медиаинформации приводят к многочисленным нарушениям, обусловливают растущую идеологическую поляризацию.

В Казахстане омни-медиатизация стала стратегией политических партий и оппозиционных движений. Мариямгуль Кусаинова анализирует трансгрессивную концепцию трансмедийного повествования как перспективное направление этих стратегий. Автор доказывает, что основными чертами медиатизации государственной политики в Казахстане являются патерналистский формат взаимодействия и политическая коммуникация в социальных сетях для защиты общества от суррогатной оппозиции, роста политического популизма и дезинформации.

Джан Билгили и Елена Горошко сосредоточились на изучении взаимосвязи СМИ с осведомленностью аудитории о содержании контента трансмедийных историй в контексте медиаграмотности. Исследователи сфокусировались на изучении понимания турецкой и украинской аудиторией трансмедийных проектов. Особое внимание ученые уделили изучению компетентностей пользователей социальных сетей и телезрителей (телевидение для исследования было выбрано в качестве традиционного СМИ в силу его высокой популярности в двух странах). Исследование решило задачу описания переходов контента между различными медиаинструментами и платформами.

Дмитрий Шаронов анализирует концепцию гипермедиа как трансгрессивный аспект глубокой медиатизации отношений между компанией и ее стейкхолдерами и конкретизирует модель рекурсивного общения для правильной интерпретации обнаруженных явлений. Автор считает, что философская рефлексия, экологический подход и переход к трансдисциплинарным методам исследования проблем глубокой медиатизации в цифровую эпоху неизбежны.

Лариса Шарахина, Вера Ачкасова и Людмила Азарова отмечают, что медиа и окружающая среда решающим образом формируют друг друга и условия работы других институтов. Авторы впервые используют оптику медиатизации для анализа корпоративных коммуникаций и стратегий отношений со СМИ и находят определенные дискурсивные «конфигурации конфигураций», выстроенные слоями, постоянно ссылаясь друг на друга.

В эпоху социальных сетей социальные институты находятся под влиянием медиа, в частности в медицине. Марина Шутова и Яна Рочева сосредоточили внимание на новых цифровых опосредованных моделях взаимодействия от клиники к врачу и пациенту. Новаторское исследование преобразующего эффекта медиатизации в медицине раскрывает эффективность коммуникативного конструктивизма, подтверждает тенденции трансформации в медицине как социальном институте и стирает границы традиционной области исследований.

Растущая повсеместная дигитализация медиатизированной коммуникации, особенно в «новой нормальности», определяет интерес Елены Чанко- 
вой и Олега Сорокина к феномену коммуникативной компетентности личности. Исследователи полагают, что коммуникативная компетентность человека определяет эффективность взаимодействий в контексте технологических, семантических и институциональных изменений и интеграции коммуникативного пространства общества.

В третьем разделе выпуска читатель может сравнить реалии медиатизации в глобальном и локальном теоретическом контексте, читая интервью с ведущими исследователями в своих областях - профессором Андреасом Хеппом и профессором Уильямом Даттоном.

Вопросы исследования медиатизации по-прежнему открыты. Исследователи данного специального выпуска «Медиатизация в цифровую эру: от транзита к трансгрессии», создавая карту медиатизации в «новой нормальности», являются первопроходцами — в прямом и переносном смысле. Давайте вместе с ними пересечем все границы, потому что только внешний наблюдатель любой системы получает возможность взглянуть на нее объективно, что особенно важно для ученого. Приятного вам путешествия и удачи!

\section{References}

[1] Žižek, S. (2020). Pandemic!: COVID-19 Shakes the World. OR Books. doi: 10.2307/ j.ctv16t6n4q

[2] Fuchs, Ch. (2021). Communicating COVID-19: Everyday Life, Digital Capitalism, and Conspiracy Theories in Pandemic Times. Bingley Emerald.

[3] Liu, Zhenmin. (2021). The post-COVID-19 era will bring forward a new normal. Retrieved May 20, 2021, from https://www.un.org/development/desa/undesavoice/ feature/2020/11\#50277

[4] Couldry, N., \& Mejias, U. (2019). The Costs of Connection. How Data Is Colonizing Human Life and Appropriating It for Capitalism. Stanford University Press.

[5] Experts Say the "New Normal" in 2025 Will Be Far More Tech-Driven, Presenting More Big Challenges. Retrieved May 20, 2021, from https://www.pewresearch.org/ internet/2021/02/18/experts-say-the-new-normal-in-2025-will-be-far-more-tech-drivenpresenting-more-big-challenges/

[6] Hepp, A., \& Krotz, F. (Eds.) (2014). Mediatized Worlds. Culture and Society in a Media Age. Basingtoke: Palgrave Macmillan.

[7] Thompson, J.B. (1995). The Media and Modernity. A Social Theory of the Media. Cambridge. Retrieved May 20, 2021, from https://johnpostill.com/2010/03/30/com munication-and-social-context-thompson-1995/

[8] Fornäs, J. (2014). Mediatization of popular culture. In: K. Lundby (Ed.), Mediatization of Communication: Handbooks of Communication Science (Vol. 21, pp. 483-504.). Berlin: De Gruyter Mouton.

[9] Livingston, S. (2008). On the mediation of everything: ICA presidential address. Journal of communication, 59(1), 1-18. doi: 10.1111/j.1460-2466.2008.01401.x

[10] Lunt, P., \& Livingstone, S. (2015). Is "mediatization" the new paradigm for our field? A commentary on Deacon and Stanyer $(2014,2015)$ and Hepp, Hjarvard and Lundby. Media, Culture and Society. Retrieved May 20, 2021, from http://eprints.lse.ac.uk/ 63409

[11] Hjarvard, S. (2013). The Mediatization of Culture and Society. London: Routledge. 
[12] Schultz W. (2004). Reconstructing mediatization as an analytical concept. European Journal of Communication, 19(1), 87-101.

[13] Krotz, F. (2007). The meta-process of 'mediatization' as a conceptual frame. Global Media and Communication, 3(3), 256-260. doi: 10.1177/17427665070030030103

[14] Hjarvard, S., \& Peterson, L.N. (2013). Mediatization and cultural change. MedieKultur, $54,3$.

[15] Elias, N. (1978). What Is Sociology? New York: Columbia University Press.

[16] Couldry, N., \& Hepp, A. (2016). The Mediated Construction of Reality. Cambridge, UK; Malden, MA: Polity Press.

[17] Hepp, A. (2020). Deep mediatization. Routledge.

[18] ICA (2020). Conference. Retrieved May 20, 2021, from https://www.hans-bredowinstitut.de/en/news/70th-annual-conference-of-the-international-communication-asso ciation-ica-2020

[19] Kumar, Putta, S., \& Anderson, B. (2021). Deep Mediatization during COVID-19: An Interview with Professor Andreas Hepp, University of Bremen. Networking Knowledge, 14(1), 125-130. doi: 10.31165/nk.2021.141.662

[20] Shilina, M. (2020). Public relations in the context of mediatization: the formation of a conceptual framework for research. Bulletin of the Peoples' Friendship University of Russia. Series: Literary criticism. Journalism, 25(3), 521-530 doi: 10.22363/23129220-2020-25-3-521-530 (In Russ.)

[21] Shilina, M. (2020). Data Turn and Datascape in Russia. In S. Davydov (Ed.) Internet in Russia. Springer Nature Switzerland AG (pp. 171-197). Retrieved May 20, 2021, from https://mail.google.com/mail/u/0/\#search/sdavydov\%40hse.ru/FMfcgxwHNCxSBxwW NvWZCPPDRvnZKKDs?projector $=1 \&$ messagePartId $=0.1$

[22] Silverstone, R. (2005). The sociology of mediation and communication. In Calhoun, C.J., Rojek, C., \& Turner, B.S. (Eds.), The Sage Handbook of Sociology (pp. 188-207). London: Sage Publications.

[23] Krotz, F. (2009). Mediatization: a concept with which to grasp media and societal change. In K. Lundby (Ed.), Mediatization: Concept, Changes, Consequences (pp. 2140). New York: Peter Lang.

[24] Jenks, C. (2003). Transgression. Routlege.

[25] Blanchot, M. (1994). Experience-limit. Thanatography of Eros: Georges Bataille and French Thought of the Mid-20th Century (pp. 63-77). SPb.: Mithril. (In Russ.)

[26] Bataille, J. (1997). Inner Experience. SPb.: Axiom; Mithril. (In Russ.)

Батай Ж. Внутренний опыт. СПб.: Аксиома; Мифрил, 1997.

[27] Schmitt, K. (2000). Political Theology. In Political Theology. Collection (pp. 7-98). Moscow: KANON-press-Ts. (In Russ.)

[28] Gournels, T., \& Gunkel, D.J. (2012) Transgression 2.0: media, culture and politics of a digital age. Bloomsbury Academic.

[29] Bakhtin, M. (1965). Creativity of Francois Rabelais and folk culture of the Middle Ages and Renaissance. Fiction. (In Russ.)

[30] Transgressive Media Culture. Amsterdam University Press. Retrieved May 20, 2021, from https:// www.aup.nl/en/ series/transgressive-media-culture

[31] Hermes, J., \& Hill, A. (2021). Transgression in contemporary media culture. International Journal of Cultural Studies Retrieved May 20, 2021, from https://journals.sagepub. com/doi/abs/10.1177/1367877920968105

\section{Библиографический список}

[1] Žižek S. Pandemic!: COVID-19 Shakes the World. OR Books, 2020. URL: https:// doi.org/10.2307/j.ctv16t6n4q (accessed: 20.05.2021). 
[2] Fuchs Ch. Communicating COVID-19: Everyday Life, Digital Capitalism, and Conspiracy Theories in Pandemic Times. Bingley Emerald, 2021.

[3] Liu Zhenmin. The post-COVID-19 era will bring forward a new normal. URL: https://www.un.org/development/desa/undesavoice/feature/2020/11\#50277 (accessed: 20.05.2021).

[4] Couldry N., Mejias U. The Costs of Connection. How Data Is Colonizing Human Life and Appropriating It for Capitalism. Stanford University Press, 2019.

[5] Experts Say the 'New Normal' in 2025 Will Be Far More Tech-Driven, Presenting More Big Challenges. URL: https://www.pewresearch.org/internet/2021/02/18/expertssay-the-new-normal-in-2025-will-be-far-more-tech-driven-presenting-more-big-challenges/

[6] Mediatized Worlds. Culture and Society in a Media Age / Hepp A., Krotz F. (Eds.). Basingtoke: Palgrave Macmillan, 2014.

[7] Thompson J.B. The Media and Modernity. A Social Theory of the Media. Cambridge. URL: https://johnpostill.com/2010/03/30/communication-and-social-context-thompson1995 (accessed: 20.05.2021).

[8] Fornäs J. Mediatization of popular culture // K. Lundby (Ed.). Mediatization of Communication: Handbooks of Communication Science. Vol. 21. Berlin: De Gruyter Mouton, 2014. P. 483-504.

[9] Livingston $S$. On the mediation of everything: ICA presidential address // Journal of communication. Vol. 59. № 1. P. 1-18. doi: 10.1111/j.1460-2466.2008.01401.x

[10] Lunt P., Livingstone $S$. Is 'mediatization' the new paradigm for our field? A commentary on Deacon and Stanyer (2014, 2015) and Hepp, Hjarvard and Lundby (2015) // Media, Culture and Society. URL: http://eprints.lse.ac.uk/63409 (accessed: 20.05.2021).

[11] Hjarvard S. The Mediatization of Culture and Society. London: Routledge, 2013.

[12] Schultz W. Reconstructing mediatization as an analytical concept// European Journal of Communication. 2004. Vol. 19. № 1. P. 87-101.

[13] Krotz F. The meta-process of 'mediatization' as a conceptual frame. Global Media and Communication. 2007. Vol. 3. № 3. P. 256-260. doi: 10.1177/17427665070030030103

[14] Hjarvard S., Peterson L.N. Mediatization and cultural change // MedieKultur. 2013. Vol. 54. № 3.

[15] Elias N. What Is Sociology? New York: Columbia University Press, 1978.

[16] Couldry N., Hepp A. The Mediated Construction of Reality. Cambridge, UK; Malden, MA: Polity Press, 2016.

[17] Hepp A. Deep mediatization. Routledge, 2020.

[18] ICA 2020. Conference. URL: https://www.hans-bredow-institut.de/en/news/70th-an nual-conference-of-the-international-communication-association-ica-2020 (accessed: 20.05.2021).

[19] Kumar C., Putta S., Anderson B. Deep Mediatization during COVID-19: An Interview with Professor Andreas Hepp, University of Bremen // Networking Knowledge, 2021. Vol. 14. № 1. P. 125-130. https://doi.org/10.31165/nk.2021.141.662

[20] Шилина М.Г. Связи с общественностью в контексте медиатизации: формирование концептуальной рамки исследования // Вестник Российского университета дружбы народов. Серия: Литературоведение. Журналистика. 2020. Т. 25. № 3. С. 521530. URL: doi: 10.22363/2312-9220-2020-25-3-521-530

[21] Shilina M. Data Turn and Datascape in Russia // S. Davydov (Ed.). Internet in Russia, 2020. Springer Nature Switzerland AG. P. 171-197. URL: https://mail.google.com/ mail/u/0/\#search/sdavydov\%40hse.ru/FMfcgxwHNCxSBxwWNvWZCPPDRvnZKKDs? projector $=1 \&$ messagePartId $=0.1$ (accessed: 20.05 .2021 ).

[22] Silverstone R. The sociology of mediation and communication // Calhoun C.J., Rojek C. Turner B.S. The Sage Handbook of Sociology. London: Sage Publications, 2005. P. 188-207. 
[23] Krotz F. Mediatization: a concept with which to grasp media and societal change // Lundby K. Mediatization: Concept, Changes, Consequences. New York: Peter Lang, 2009. P. 21-40.

[24] Jenks C. Transgression. Routlege, 2003.

[25] Бланшо М. Опыт-предел. Танатография эроса: Жорж Батай и французская мысль середины ХХ века. СПб.: Мифрил, 1994. С. 63-77.

[26] Батай Ж. Внутренний опыт. СПб.: Аксиома, Мифрил, 1997.

[27] Шмитт К. Политическая теология. М.: Канон-Пресс-Ц, 2000. С. 7-98.

[28] Gournels T., Gunkel D.J. Transgression 2.0: media, culture and politics of a digital age. Bloomsbury Academic, 2012.

[29] Бахтин М.М. Творчество Франсуа Рабле и народная культура средневековья и Ренессанса. М.: Худ. лит-ра, 1965.

[30] Transgressive Media Culture. Amsterdam University Press. URL: https://www.aup.nl/en/ series/transgressive-media-culture

[31] Hermes J., Hill A. Transgression in contemporary media culture // International Journal of Cultural Studies. URL: https://journals.sagepub.com/doi/abs/10.1177/136787792096 8105 (accessed: 20.05.2021).

\section{Bio note:}

Marina G. Shilina, Professor, Plekhanov Russian University of Economics, Lomonosov Moscow State University, ORCID: 0000-0002-9608-352X; e-mail: marina.shilina@gmail.com

\section{Сведения об авторе:}

Шилина Марина Григорьевна, профессор РЭУ имени Г.В. Плеханова, МГУ имени M.В. Ломоносова, ORCID: 0000-0002-9608-352X; e-mail: marina.shilina@gmail.com 